\title{
Patellofemoral Arthrosis and Patellofemoral Arthroplasty
}

\author{
Patellofemoral Artroz ve Patellofemoral Artroplasti \\ Barış Yılmaz', Güzelali Özdemir', Baran Kömür², Serhat Mutlu², Bülent Yücel², Harun Mutlu³ \\ ${ }^{1}$ Clinic of Orthopedics and Traumatology, Fatih Sultan Mehmet Training and Research Hospital, ìstanbul, Turkey \\ ${ }^{2}$ Clinic of Orthopedyics and Traumatology, Kanuni Sultan Süleyman Training and Research Hospital, İstanbul, Turkey \\ ${ }^{3}$ Clinic of Orthopedics and Traumatology, G.O.P Taksim Training and Research Hospital, i̇stanbul, Turkey
}

\begin{abstract}
The patellofemoral joint tends to develop osteoarthritis due to the high rates of anatomical abnormalities and exposure to large weights through relatively small areas. The rate of isolated patellofemoral arthrosis is $11 \%$ in men and $24 \%$ in women above 55 years of age. This gender difference may be due to the more frequent presence of patellar aligment problems and dysplasia in women. Although, patellofemoral arthrosis, in general, is treated by conservative methods, surgery should be considered for patients who have failed to benefit from weight loss, physical therapy and drug treatment because the disease leads to pain and loss of function. In the surgical treatment of patellofemoral arthrosis, methods such as arthroscopic debridement, management of loads that affect the patella, cartilage grafting, patellar resurfacing, patellafemoral arthroplasty (PFA), total joint replacement and patellectomy can be used. However, PFA has not been widely used. The reasons were problems with the initial design, and mistakes in patient selection, but those were reduced recently and this has led to increasing interest in the PFA. The current indications of PFA comprise of patients with little or no malalignment, and young patients with isolated patellofemoral disease who were planned for patellectomy due to symptom severity. Indeed, the outcomes from patients who were below 55 years of age with a 5-year follow up are promising. (JAREM 2014; 1: 1-3)
\end{abstract}

Key Words: Patellafemoral joint, arthrosis, patellofemoral arthroplasty

\section{ÖZET}

Patellofemoral eklem büyük yüklerin dar temas alanları üzerinden etki etmesi ve nispeten anatomik anomali oranının sıklığı nedeniyle osteoartrite oldukça meyilli bir eklemdir. Tek başına patellofemoral artroz varlığı 55 yaş üstü erkeklerde \%11, kadınlarda \%24 oranında görülmekle birlikte bu cinsiyet farklılı̆ının nedeni kadınlarda daha sık olan patellar dizilim bozukluğu ve displazi olabilir. Patellofemoral artroz genellikle konservatif yöntemler ile tedavi edilmeye çalışılsa da; tek başına ağrı ve fonksiyon kaybı yaratması nedeniyle kilo verme, fizik tedavi ve ilaç tedavisinden fayda görmeyen hastalar için cerrahi seçenekler gözönünde bulundurulmalıdır. Patellofemoral artroz cerrahi tedavisinde artroskopik debridman, patellayı etkileyen yüklerin düzenlenmesi, kıkırdak greftlemeleri, patellar yüzey yenilemeleri, Patellofemoral artroplasti (PFA), total eklem replasmanı ve patellektomiye uzanan yöntemler uygulanabilmektedir. Bununla birlikte PFA çok yaygın kullanım alanı bulamamıştır. Bunun nedeni olarak gösterilen ilk tasarımlardaki sorunlar ve hasta seçimindeki hata oranlarının azaltılması ile özellikle son yıllarda PFA'ye olan ilgi de artmıştır. PFA'nin günümüzdeki endikasyonları arasında yanlış dizilimin çok az olduğu ya da hiç olmadığı hastalar ve semptomların ciddiyeti nedeniyle patellektomi planlanan izole patellofemoral hastalığı olan genç hastalar vardır. Gerçekten de 55 yaş altı ve en az 5 yıllık takibi olan hastaların sonuçları cesaret vericidir. (JAREM 2014; 1: 1-3)

Anahtar Sözcükler: Patellofemoral eklem, artroz, patellofemoral artroplasti

\section{INTRODUCTION}

The patellofemoral joint is a part of the knee and is located between the femoral condyles and patella. This joint is affected by various loads at different flexion angles. When the knee is fully extended, load on the patellofemoral joint is minimal, whereas the load becomes at the largest level at $60^{\circ}$ to $90^{\circ}$ flexion (1). In other words, at $10^{\circ}$ knee flexion, the load on the patellofemoral joint equals to half the body weight, whereas it may be 3.5 -fold body weight at $60^{\circ} \mathrm{knee}$ flexion. During difficult activities such as ascending or descending the stairs, the load on the patellofemoral joint may be 8 times the body weight (2). Between $0^{\circ}$ to $30^{\circ}$ flexion, dynamic stability of the patellofemoral joint is achieved by musculus vastus medialis obliqus, whereas static stability is achieved by the medial patellofemoral ligament. At further degrees of flexion movements, stability is achieved by bony structures following patellar sliding into the trochlear sulcus (3). However, the patellofemoral joint is actually accepted as the joint of extensor muscles since this joint lengthens the force arm of the quadriceps femoris muscle and changes the direction of muscle force. Thus, it plays an important role in knee stability. Therefore, patellofemoral joint problems may be considered as the problems of the knee extensor mechanism $(4,5)$.

Complaints arising from the patellofemoral joint occur during movements against gravity. The primary complaint is pain behind the patella, medial to the joint, and sometimes at the popliteal fossa. This kind of pain intensifies during activities such as ascending the stairs, sitting with knees at flexion, and squatting $(6,7)$. At times, pain can be bilateral and, in general, it is not related to any trauma. Among the other complaints, patients frequently report sounds from the patellofemoral joint, feeling of uncoil or instability, and locking. These symptoms stem from impairment of the normal rhythmic movement of the patellofemoral joint $(8,9)$. Sensation of friction may be prominent, especially when the load on the patellofemoral joint is increased during ascending stairs and, rarely, it may be heard. Most of the patients with patellofemoral joint disease show effusion of the knee joint. Quadriceps atrophy may be seen in chronic cases.

Diagnosis should be based on at least anteroposterior and lateral x-ray radiography of knee. Tunnel and tangential patella 
radiographies may frequently be added. Tangential patella radiography mostly involved Merchant and Mountain techniques in the literature. These radiographies show the patellofemoral joint. Although they are not routine, oblique radiographies may be necessary. Computerized tomography (CT) imaging of the patellofemoral joint enables evaluation of the patella and femoral condyle contours. CT arthrography may show retropatellar and trochlear articular cartilage and synovial surfaces. Magnetic resonance imaging (MRI) may be preferred in the diagnosis of patellofemoral joint diseases, as it is non-invasive and enables evaluation of bone, cartilage and soft tissues. The imaging plane is not confined to the transverse plane as in CT. It may provide imaging in all planes and it does not involve ionizing radiation. When necessary, arthroscopy is one of the most important current diagnostic and interventional methods $(10,11)$.

The patellofemoral joint tends to develop osteoarthritis due to high rates of anatomical abnormalities and exposure to large weights through relatively small areas. Lateral patellofemoral joint involvement frequently accompanies lateral and medial femorotibial joint osteoarthritis. However, patellofemoral joint involvement may be isolated. Involvement of the medial patellofemoral joint is rare. The rate of isolated patellofemoral arthrosis is $11 \%$ in men and $24 \%$ in women above 55 years of age. This gender difference is due to the more frequent presence of patellar alignment problems and dysplasia in women $(12,13)$.

Although conservative methods are preferred in the treatment of patellofemoral arthrosis, surgery should be considered for patients who fail to benefit from weight loss, physical therapy and drug treatment because the disease leads to pain and loss of function. In the surgical treatment of patellofemoral arthrosis, methods such as arthroscopic debridement, management of loads that affect the patella, cartilage grafting, patellar resurfacing, PFA, total joint replacement and patellectomy can be used (14). However, PFA has not been widely used. The reasons were problems with the initial design, and mistakes in patient selection, but those were reduced recently and this has led to increasing interest in PFA $(15,16)$.

\section{DISCUSSION}

The first report on patellofemoral arthroplasty was published by McKeever in 1955 which was an report of a successful prosthesis approach in patients with symptomatic isolated patellofemoral degenerative disease. Initial results showed that PFA was a good alternative to patellectomy and patellar skiving in the treatment of patellar osteoarthritis (17). In 1973, Levitt supported those results in his study and suggested that patellar resurfacing is a good alternative in the treatment of patellofemoral osteoarthritis. Subsequently, 39 of 45 patients reported that they were pleased with the McKeever prosthesis during 22 year follow up. In 1979, Blazina et al. (18) published the first report of patellar resurfacing and gave rise to PFA applications in the literature. Later studies reported a success rate of $44 \%$ to $90 \%$ for PFA. However, a $50 \%$ failure in 76 knees with a Lubinus prosthesis in 8 years was reported (19) and the main reasons for this failure were reported to be malalignment, wear and tear, repeated traumas and disease progression. New designs with shallow and wide femoral rims that enabled better fixation of the trochlea during flexion were developed. In addition, these designs allowed total replacement when the disease progressed $(20,21)$. Among the features of the new products, intramedullary instrumentation, wider size choices, minimal incision technique, longer cement and polyethylene forms, trochlear rims with superolateral extension which increase patellar clutch and trachlear angle that may reduce patellar prosthesis application problems can be listed. The purpose is to achieve success rates close to total knee prosthesis with normal knee kinematics. Results from the literature demonstrate that these sophisticated designs eliminate wrong alignment and early abrasion. Low complication rates and excellent range of motion were reported. Disease progression in the tibiofemoral joint is a problem that remains to be solved. These types of new design prostheses present an alternative treatment for total joint replacement in patients with isolated patellofemoral disease (Figure 1, 2) (22, 23).

The current indications of PFA are patients without alignment problems and young patients who have severe symptoms and are planned for patellectomy due to isolated patellofemoral disease. An important advantage of this treatment is that meniscus and cruciate ligaments and thus the natural structure of the knee joint are preserved. The outcomes of a -5 year follow up in patients below 55 years of age are promising. In this group, the underlying reason is mostly the secondary osteoarthritis. Osteoarthritis results from isolated traumas such as patellar fracture, thus other parts of the knee are not affected, and disease progression in the tibiofemoral joint is slower $(23,24)$.

Philippe $\mathrm{H}$. and Caton J. of France reported the results of 70 PFA with a 10-year follow up and they observed no complication of arthroplasty and 3 of 5 patients underwent revision surgery due to progression of tibiofemoral joint disease. Four patients had

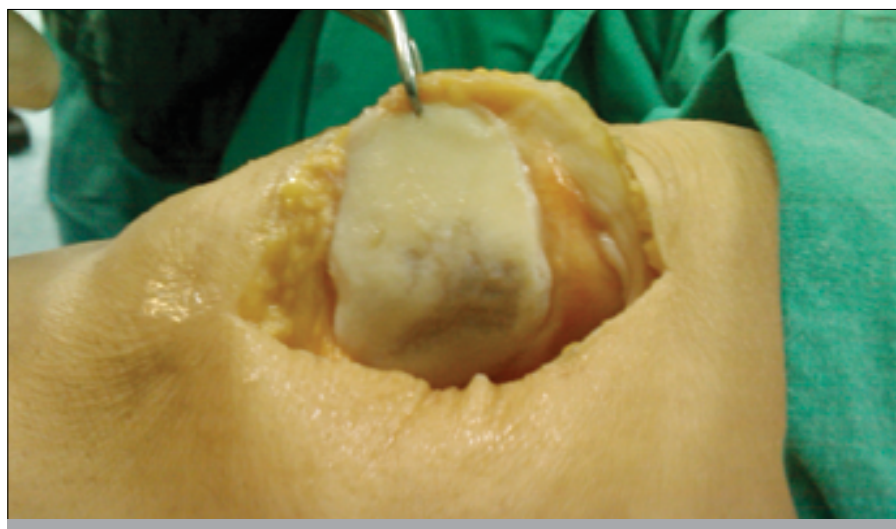

Figure 1. Full thickness cartilage defect of the patella

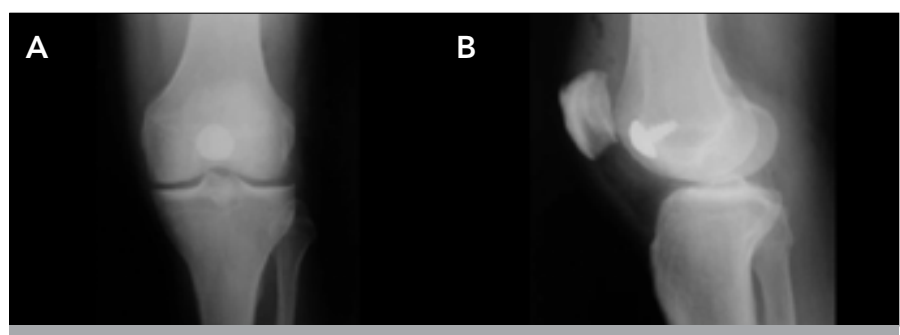

Figure 2. Postoperative $A P$ and lateral view following patellar resurfacing 
intractable anterior knee pain, whereas the other four patients had slight patellar lateral subluxation. This implant was reported to be a good alternative to total knee prosthesis, with the same safety profile in patients with isolated patellofemoral disease (25).

Van Jonbergen HPW et al. (26) investigated the stress distribution differences in the distal femur of patients who underwent patellofemoral joint arthroplasty and total knee arthroplasty. Patellofemoral joint arthroplasty forms a stress shield around the prosthesis, but this is less than total knee arthroplasty. They suggested that special designs of patellofemoral prostheses may result in differences of the femoral stress shield (26).

\section{CONCLUSION}

Patellofemoral Artroplasti alone is efficient in patients with patellofemoral arthrosis and middle-term follow up showed goodexcellent results in $90-95 \%$ of the patients. On the other hand, anterior knee pain rates of 7-19\% and better knee society scores of total knee arthroplasty, for arthrosis involving three compartments of the knee when compared to PFA, stress the importance of correct patient selection. In current practice, despite lack of any rule regarding age, PFA may be a better choice than total knee arthroplasty or patellectomy in knee anterior compartment arthrosis patients who are younger than 55 years of age $(27,28)$.

Peer-review: Externally peer-reviewed.

Author Contributions: Concept - B.Y., S.M., H.M.; Design - S.M., H.M.; Supervision - B.K., B.Y.; Funding - S.M., B.Y., G.Ö.; Materials - B.Y., S.M.; Data Collection and/or Processing - S.M., H.M., B.K.; Analysis and/or Interpretation - G.Ö, B.Y.; Literature Review - B.K., H.M.; Writing - H.M., S.M., B.Y.; Critical Review - B.Y., H.M.; Other - S.M., B.Y.;

Conflict of Interest: No conflict of interest was declared by the authors.

Financial Disclosure: The authors declared that this study has received no financial support.

Hakem Değerlendirmesi: Dış bağımsız.

Yazar Katkıları: Fikir - B.Y., S.M., H.M.; Tasarım - S.M., H.M.; Denetleme - B.K., B.Y.; Kaynaklar - S.M., B.Y., G.Ö.; Malzemeler - B.Y., S.M.; Veri toplanması ve/veya işlemesi - S.M., H.M, B.K.; Analiz ve/veya yorum - G.Ö., B.Y.; Literatür taraması - B.K., H.M.; Yazıyı yazan - H.M., S.M., B.Y.; Eleştirel İnceleme - B.Y., H.M.; Diğer - S.M., B.Y.

Çıkar Çatışması: Yazarlar çıkar çatışması bildirmemişlerdir.

Finansal Destek: Yazarlar bu çalışma için finansal destek almadıklarını beyan etmişlerdir.

\section{REFERENCES}

1. Mikosz RP, Andriacchi TP. Anatomy and biomechanics of the knee. Callaghan JJ (ed). OKU. Rosemont, American academy of orthopaedic surgeons, 1995: 227.

2. Dingwall I. Biomechanics of the knee. Barrett D. Essential basic sciences for orthopaedics. Trombridge, Butterworth- heinmann Itd, 1994; 94.

3. Fulkerson JP, Hungerford DS. Biomechanics of the patellofemorel joint. William wilkins, Baltimore, 1990; 35.

4. Conlan T, Garth WP Jr, Lemons JE. Evalotion of the medial sotf tissue restrains of the ekstansor mechanism of the knee. JBJS. 75-A, 1993; 682.

5. Erdemli B, Baynakçı K, Güzel B, Çetin I. Patellar yüzeyi degiştirilen total diz protezi olgularında ekstansör mekanizma sorunları.Acta Orthop Traumatol Turc 1998; 32: 287-90.
6. William M. Mihalko, MD, PhD, Yaw Boachie-Adjei, MD, Jeffrey T. Spang, MD, John P. Fulkerson, MD,Elizabeth A. Arendt, MD, and Khaled J. Saleh, MD, MSc(Epid), FRCSC.Controversies and Techniques in the Surgical Management of Patellofemoral Arthritis. The Journal of bone\&Joint surgery d JBJ S. ORG 2007; 89: 2788-802.

7. Sar C, Göksan SB, Tözün «R, Çakmak M, Çetinkaya S. Total diz artroplastisinde patellofemoral eklem. Acta Orthop Traumatol Turc 1994; 28: 338-40.

8. Bullogh P, Cawston T. Pathology and biochemistry of osteoarthritis. Osteoarthritis 1994; 29-58.

9. Post WR.Clinical evaluation of patients with patellofemoral disorders. Arthroscopy 1999; 15: 841-51. [CrossRef]

10. Ateşalp A. Patellofemoral eklemin görüntülenmesi Bölüm II. Acta Orthop Traumatol Turc 1995; 29: 361-8.

11. Merchant AC, Mercer RL, Jacobsen RH, Cool CR. Roentgenographic analysis of the patellofemoral congruence. J Bone Joint Surg Am 1974; 56: 1391-6.

12. McAlindon TE, Snow S, Cooper C, Dieppe PA. Radiographic patterns of osteoarthritis of the knee joint in the community: the importance of the patellofemoral joint.Ann Rheum Dis 1992; 51: 844-9. [CrossRef]

13. Laskin RS, van Steijn M. Total knee replacement for patients with patellofemoral arthritis. Clin Orthop Relat Res 1999; 367: 89-95. [CrossRef]

14. Güçlü B, Kuru i. Patellofemoral artroz ve artroplasti. TOTBID dergisi 2012; 11: 352-6. [CrossRef]

15. Parvizi J, Stuart MJ, Pagnano MW, Hanssen AD. Total knee artroplasty in patients with isolated patellofemoral arthritis.Clin Orthop Relat Res 2001; 392: 147-52. [CrossRef]

16. Aglietti P, Insall JN, Walker PS, Trent P. A new patella prosthesis. Design and application.Clinn Orthop Relat Res 1975; 107: 175-87. [CrossRef]

17. McKeever DC. Patellar prosthesis. J Bone Joint Surg Am. 1955; 37: 1074-84

18. Blazina ME, Fox JM, Del Pizzo W, Broukhim B, Ivey FM. Patellofemoral Replacement. Clinical Orthopaedics and Related Research, 2005; 436: 3-6. [CrossRef]

19. Tauro B,Ackroyd CE, Neuman JH, Shah NA. The Lubinus patellofemoral arthroplasty. A five- to tenyear prospective study. J Bone Joint Surg $\mathrm{Br}$ 2001; 83: 696-701. [CrossRef]

20. Kooijman, H. J.; Driessen, A. P. P. M.; and van Horn, J. R.: Long Term Results of Patellofemoral Arthroplasty. Journal of Bone \& Joint Surgery 2003; 85: 836-40.

21. Krajca-Radcliffe JB, Coker TP. Patellofemoral Arthroplasty: A 2- to 18Year Follow-up Study. Clinical Orthopaedics and Related Research 1996; 330: 143-51. [CrossRef]

22. Lonner JH. Patellofemoral arthroplasty. J Am Acad Orthop Surg 2007; 15: 495-506.

23. Boucher HR. Patellofemoral arthroplasty. Current Opinion in Orthopadics 2006; 17: 47-50. [CrossRef]

24. Leadbetter WB, Ragland PS, Mont MA. The appropriate use of patellofemoral arthroplasty: an analysis of reported indications, contraindications, and failures. Clin Orthop Relat Res 2005; 436: 91-9. [CrossRef]

25. Philippe H., Caton J. Design, operative technique and ten-year results of the Hermes patellofemoral arthroplasty. Int Orthop. 2013 Nov. (Epub ahead of print).

26. Van Jonbergen HPW, Innocenti B, Gervasi GL, Labey L, Verdonschot $N$. Differences in tha stress distribution in the distal femur between patellofemoral joint replacement and total knee replacement: a finite element study. J Orthop Surg Res 2012; 15; 7: 28.

27. Erduran M, Akseki D, Karaoğlan O, Pınar H. Patellofemoral joint dynamics in patients with gonarthrosis. Joint diseases and related surgery 2009: 20: 18-24.

28. Lustig S, Magnussen RA, Dahm DL, Parker D. Patellofemoral arthroplasty, where are we today? Knee Surg Traumatol Arthrosc 2012; 20: 1216-26. [CrossRef] 